Arhe XVIII, 35/2021

UDK 2-1 Kant I.

DOI https://doi.org/10.19090/arhe.2021.35.143-162

Originalni naučni rad

Original Scientific Article

SAFER GRBIĆ ${ }^{1}$

Sveučilište u Zagrebu, Filozofski fakultet, Republika Hrvatska

\title{
IZLAGANJE KANTOVE KRITIKE RACIONALNE TEOLOGIJE KAO PRILOGA TEZI O NESUVISLOSTI RELIGIJSKIH SUKOBA
}

Sažetak: Koji značaj ima Kantova kritika metafizike i posebice jedna kritika racionalne teologije u kontekstu pitanja nesuvislosti religijskih sukoba? Upravo, glede toga odnosa, u ovomu radu će biti razmatrana kratka povijest mišljenja jednoga fenomena imenovanoga kao racionalna teologija, potom će biti u tomu kontekstu razmatrano Kantovo pretkritičko djelo i docnije izlaganje jedne kritike racionalne teologije, a sve u kontekstu dovođenja u pitanje odnos pobrojanoga $\mathrm{s}$ religijskim sukobima. Hipoteza ovoga rada se ogleda u dokazivanju odnosa između Kantove kritike racionalne teologije i ideje nesuvislosti religijskih sukoba na način da se nesuvislost religijskih sukoba temelji zapravo u rezultatima Kantovoga kriticizma: nemogućnosti uspostave ontologijskog, kozmologijskog i fizikoteologijskog ili teleologijskog dokaza za egzistenciju religijske ideje Boga na nivou objektivnosti, izvjesnosti i znanja. Dakle, naposljetku, a shodno rezultatima Kantovoga glavnog djela Kritik der reinen Vernunft: zašto uopće ozbiljivati religijske sukobe kada ne možemo objektivno dokazati egzistenciju religijske ideje Boga - zbog koje se sāmi religijski sukobi po svojoj definiciji i ozbiljuju!?

Ključne riječi: spoznajna teorija, teologijska epistemologija, racionalna teologija, Immanuel Kant, religijski sukobi, triplet, objava, razum, srce

\footnotetext{
${ }^{1}$ E-mail adresa autora: safergrbic@hotmail.com
} 


\subsection{KRATKA POVIJEST MIŠLJENJA JEDNOGA FENOMENA IMENOVANOGA KAO RACIONALNA TEOLOGIJA ${ }^{2}$}

Religijski sukobi - kao sukobi prevalvirajućeg karaktera nakon moderne - odvijaju se unutar jednog religijskog entiteta za razliku od predominantnih sukoba religija - kao sukoba različnih religijskih entiteta koji su obilježili tijek povijesti. Ipak, religijski sukobi nisu nastali izvorno tek sa modernom: negoli od čina objektivizacije subjektivno dostatnih vjerovanja gdje su religijski sukobi vođeni kroz religijsku literaturu do institucionaliziranja religijskih institucija gdje su religijski sukobi poprimili obličje mortalnosti. ${ }^{3}$ Povijest religijskih sukoba u tomu kontekstu počinje pitanjem spoznajne teorije kao primordijalnim oblikom teologijskih epistemologija, naime. Teologijska epistemologija - koja se očituje primarno $\mathrm{u}$ epistemologiji fundamentalne teologije, epistemologiji racionalne teologije, epistemologiji spiritualne teologije i/ili rubnim teologijskim epistemologijama - tijekom povijesti religija davala se na različne načine i u svojim počecima svakako primordijalno. ${ }^{4}$ Upravo takva primordijalnost iz pozicije suvremenosti je vidljiva u ranoj religijskoj literaturi u raspravama o odnosu tripleta: objava - razum - srce..$^{5}$ Kada govorimo o primordijalnosti spoznajne teorije i suvremenom viđenju teologijske epistemologije tada zapravo spoznajnu teoriju razumijevamo kao teoretiziranje na području principa o mogućnosti jednog načina spoznaje, dok samu epistemologiju razumijevamo kao nastojanje znanstvenog ekspliciranja produkata same

\footnotetext{
${ }^{2}$ Kratka povijest mišljenja jednoga fenomena imenovanoga kao racionalna teologija nastala je kao rezultanta studentskih uporednih proučavanja povijesti filozofije u kontekstu odnosa antičke filozofije i kršćanske skolastike, pa sve do raskola Svetog Rimskog Carstva. Budući da su studentske bilješke sačinjene samo u osnovnim tezama za interne potrebe preglednosti povijesti mišljenja, ovdje su predmetne bilješke kontekstualizirane i skraćene za potrebe ovoga eseja, a nekoliko godina kasnije od njihovih priređivanja.

${ }^{3}$ Usp. Bartov O., Mck P. (2010). In God's Name: Genocide and Religion in the Twentieth Century. Brooklyn: Berghahn Press.

4 Vidjeti: Grbić, S. (2018). Mišljenje religijskih sukoba kao sukobljavanje epistemologija. Theoria vol. 4 no. 4, str. 5-38.

${ }^{5}$ Usp. Gascón, A. (2007). Reason, Revelation, and Faith of the Heart. Dayton, Ohio: NACMS.
} 


\section{IZLAGANJE KANTOVE KRITIKE RACIONALNE \\ TEOLOGIJE KAO PRILOGA TEZI O NESUVISLOSTI RELIGIJSKIH SUKOBA}

spoznajne teorije nekog religijskog entiteta što se javlja u obličju teologije, pa stoga u ovomu kontekstu i govorimo o teologijskoj epistemologiji.

$\mathrm{Na}$ tomu tragu povijest religija ukazuje na različne kombinatorike spomenutog tripleta, a predmetne varijacije u spoznajnoj teoriji odvijale su se primjerice kroz pitanje odnosa razum - objava - srce na način da je dovoljan samo razum ili da je dovoljna samo objava ili da je dovoljno samo srce ili da su razum i objava i srce identitarni ili da je neophodno na prvo mjesto u spoznajnoj teoriji staviti objavu, a potom razum ili prvo staviti razum, a potom objavu ili prvo staviti razum, a potom srce ili prvo staviti srce, a potom razum ili prvo staviti srce, pa objavu ili $[\ldots]^{6}$

I, predočavajući samo dio mogućih odnošaja objava - razum - srce uviđamo evidentno poprište dijalektičkih sukoba, a stoga što se kombinatorikama glede ovoga pitanja od strane religijskih autoriteta ne nazire konačnica. Na tomu tragu, povijest religija ukazuje na mnoštvo škola mišljenja proizišlih iz takvoga stanja stvari: primjerice u jevrejskom društvu rabanite i karaite, u kršćanskom društvu franjevce i dominikance, u muslimanskom društvu mu'atezile, maturidije, ěsarije, isna-ašerije $[\ldots]^{7}$ Kada se nakon svih mogućih kombinatorika gore spomenutih odnosa postuliraju i takva određenja spoznajne teorije da se uzima samo neki dio objave na ovaj ili onaj način ili razuma ovako ili onako ili srca pod ovim ili onim uvjetima, tada se legitimno postavlja pitanje o suvislosti spoznajne teorije onih koji pretendiraju na vječite istine: no, ovaj rad nema pretenzije ulaziti u teologijske rasprave, negoli prirediti filozofijsku analizu problema racionalne teologije.

I, u ovomu kontekstu vrijedi napomenuti, naposljetku: povijest religija ukazuje kako od primordijalnih religijskih sukoba među samim religijskim autoritetima - koji su se odvijali putem religijske literature glede pitanja spomenutoga tripleta unutar spoznajne teorije - ozbiljenje religijskih sukoba poprimilo je mortalne posljedice onoga trenutka kada su religijski

\footnotetext{
${ }^{6}$ Usp. Wainwright, W. J. (2016). Reason, Revelation and Devolution. New York: Cambridge University Press.

7 Usp. Cabezón, J. I. (1998). Scholasticism: Cross-Cultural and Comparative Perspectives. Albany: SUNY Press.
} 
autoriteti zasnovali religijske entitete na nekoj od teologijskih epistemologija, a osobito nakon institucionaliziranja religijskih institucija sa sustavnim teologijskim naukom: osnivanjem religijskih institucija sa svim onim što podrazumijevaju religijske institucije - oni koji su zastupali nauk drugačiji od nauka koji je zastupala religijska institucija bivali su ubijani, protjerivani ili u najboljem slučaju zabranjeni kroz index librorum prohibitorum. $^{8}$

Napose, kao prevalvirajuća teologijska epistemologija različnih religijskih institucija na horizontu Zapada daje se epistemologija racionalne teologije - njezina kritika ozbiljena u djelu Immanuela Kanta u ovomu kontekstu ima se za dokazati kao prilog tezi o nesuvislosti religijskih sukoba.

\subsection{PROEMIUM JEDNOJ KRITICI RACIONALNE TEOLOGIJE}

Budući da je na horizontu Zapada tijekom povijesti mišljenja predominantnu ulogu zauzimala epistemologija racionalne teologije na kojoj su se zasnivali religijski entiteti i koja je uopće bila temeljni supstrat sustava teologijskog nauka različnih religijskih institucija, nije niti za čuditi što je Immanuel Kant u svojemu glavnome djelu upravo sačinio eksplikaciju jedne kritike racionalne teologije.

Svakako, Kant se nije bavio samo kritikom racionalne teologije negoli u ovomu kontekstu metaphysica-om specialis u cjelini, no racionalna teologija kao neraskidivi dio srednjovjekovne metafizike iznašla je posebno mjesto u Kantovom kriticizmu. Ipak iz pozicije suvremenosti možemo kazati da, iako Kant u svojim internim prepiskama daje naznake kako svoje glavno djelo piše prvenstveno zbog kritike racionalne kozmologije, ${ }^{9}$ i kritika racionalne kozmologije i kritika racionalne psihologije svoju nemogućnost utemeljenja nalaze upravo u opskurnom stanju stvari proizišlih iz sustava racionalne teologije. Drugim riječima: religijske institucije koje su temeljene na racionalnoj teologiji diktirale su način mišljenja i racionalnoj kozmologiji i racionalnoj psihologiji kao sastavnica metaphysica-e specialis. U tomu

\footnotetext{
${ }^{8}$ Usp. Del Val, M. (1938). Index librorum prohibitorum, SS.MI D. N. PII PP. XI iussueditus. Vatikan: Typis Poliglottis Vaticanis.

${ }^{9}$ Usp. Kant, I. (2000). Latinska djela. Zagreb: Hrvatski studiji.
} 


\section{IZLAGANJE KANTOVE KRITIKE RACIONALNE \\ TEOLOGIJE KAO PRILOGA TEZI O NESUVISLOSTI RELIGIJSKIH SUKOBA}

kontekstu kao proemijum jednoj kritici racionalne teologije trebalo bi proučiti i Kantova djela iz ranog, pretkritičkog i metafizičkog perioda, kao i perioda desetogodišnje šutnje u kojima možemo iznaći pretpostavke za Kantov budući kriticizam.

Uvjetno rečeno, proučavajući Kantov opus u cijelosti možemo nazrijeti u njegovim djelima objavljenim prije glavnoga djela Kritik der reinen Vernunft razumijevanje spram epistemologije fundamentalne teologije kada primjerice kaže da „može se, dakle, prihvatiti mogućnost imaterijalnih bića bez zabrinutosti da bude osporavana, iako bez nade da se ta mogućnost može dokazati umnim razlozima" ${ }^{10}$, što zastupnici fundamentalne teologije u svojim djelima upravo i tvrde, ali s druge strane iskazuje posebnu kritiku epistemologije spiritualne teologije čije zastupnike naziva budnim sanjarima i kritiku racionalne teologije čije zastupnike naziva sanjarima uma. Dakle, u kontekstu postavljenoga stanja stvari, Kant u svojemu metafizičkom periodu zastupa tezu kako možemo prihvatiti postojanje nekih metafizičkih entiteta dočim ne možemo dokazati njihovo postojanje kao objektivno, a napose $\mathrm{s}$ druge strane žestoko kritizira sljedbenike spiritualne teologije nazivajući ih sanjarima osjetilnosti kojima se sve svodi na namaštavanja: „onaj koji se u budnom stanju udubljuje u izmišljotine i himere, koje izlaže njegova uvijek plodna uobrazilja, toliko da se malo obazire na zamjedbe osjetila, koje su mu sada ponajvećma prilagođene, biva s pravom nazvan budnim sanjarom [...] Od budnih sanjara su prema tome sasvim različiti vidovnjaci, ne samo po stupnju nego i po vrsti. Jer oni referiraju u budnom stanju i često pri najvećoj životnosti drugih zamjedbi zamjećuju izvjesne predmete među vanjskim drugim stvarima koje zaista oko sebe zamjećuju“"11 i sljedbenike racionalne teologije kada kaže: „svi sudovi kao što je sud da moja duša ili druga bića svoje vrste pokreću tijelo, nisu ništa više nego izmišljotine. I ona nije ni izbliza tako vrijedna kao što su one u prirodnim znanostima, koje se zasnivaju na hipotezama. U

\footnotetext{
${ }^{10}$ Kant, Schelling, Schopenhauer. (2008). Ogledi o vidovitosti [Kant: Snovi jednog vidovnjaka protumačeni snovima metafizike]. Zagreb: Hrvatska sveučilišna naklada, str. 20.

${ }^{11}$ Ibid, str $44-45$.
} 
njima se ne izmišljaju nikakve osnovne snage, nego se one koje se već poznaju iskustvom samo povezuju na način primjeren pojavama. I njihova se mogućnost mora moći u svako doba dati dokazati." ${ }^{12}$ Ipak, u metafizičkom periodu, nakon kritike sljedbenika spiritualne teologije kao sanjara osjetilnosti Kant ponajviše kritizira sljedbenike racionalne teologije koje naziva sanjarima uma, a da bi u svojemu glavnome djelu Kritik der reinen Vernunft uz kritiku racionalne kozmologije i kritiku racionalne psihologije posebno se pozabavio upravo pitanjem jedne kritike racionalne teologije. Stoga kada ovdje govorimo o Kantovoj kritici racionalne teologije prvashodno uvijek govorimo o njegovoj kritici u djelu s kojim otpočinje njegov kritički period: Kritik der reinen Vernunft, a sve što je Kant prethodno pisao o problemu racionalne teologije u ovomu kontekstu držimo za proemijum.

Uzgredno: ono što je zamjetno $\mathrm{u}$ kontekstu teologijske epistemologije i Kantovog kritičkog perioda jeste sljedeće: Kant nakon kritike spiritualne teologije u metafizičkom periodu više nigdje ne problematizira nastojanja sljedbenika spiritualne teologije, a što je fenomen kojega bi se trebalo zasebice problematizirati na drugome mjestu. Naime, Kant u svojemu glavnome djelu zanima se samo i isključivo za kritiku racionalne teologije i tek uzgredno u kontekstu kritike racionalne teologije spomene metodologiju dokazivanja koja bi uvjetno rečeno odgovarala epistemologiji fundamentalne teologije, dočim o spiritualnoj teologiji ne može se iznaći niti riječi. Iako zanemaruje spiritualnu teologiju i sanjare osjetilnosti u svojemu glavnome djelu, glede pitanja epistemologije fundamentalne teologije Kant je dosljedan - od pretkritičkog, preko metafizičkog, pa čak i u kritičkom periodu kada primjerice u svojemu glavnome djelu kaže: ,ako bi neki čovjek i bio ravnodušan prema moralnim pitanjima zbog nedostatka dobre naravi $[\ldots]$ on mora dokazati nemogućnost i Boga i budućeg života, a toga se sigurno ne može poduhvatiti niti jedan uman čovjek“" ${ }^{13}$ Dakle, uvjetno rečeno, Kant prihvata stavove sljedbenika

\footnotetext{
12 Kant, Schelling, Schopenhauer. (2008). Ogledi o vidovitosti [Kant: Snovi jednog vidovnjaka protumačeni snovima metafizike]. Zagreb: Hrvatska sveučilišna naklada, str. 77.

${ }^{13}$ Kant, I. (1976). Kritika čistog uma. Beograd: BIGZ, str 493.
} 


\section{IZLAGANJE KANTOVE KRITIKE RACIONALNE \\ TEOLOGIJE KAO PRILOGA TEZI O NESUVISLOSTI RELIGIJSKIH SUKOBA}

fundamentalne teologije koji se ne bave dokazivanjem religijske ideje Boga putem razuma negoli religijsku ideju Boga razumijevaju kao subjektivno vjerovanje, dok s druge strane dokazuje nemogućnost jedne racionalne teologije na kojoj su se zasnivale i zasnivaju se većinskim dijelom religijske institucije na horizontu Zapada nastojeći od vjerovanja načiniti logički utemeljenu znanost i pretendirajući stavljanje teologijskog nauka na viši položaj izvjesnosti od matematike i prirodne znanosti. I, takav odnos religijskih autoriteta pobuđuje religijske sukobe i na tomu tragu Kantovu kritiku racionalne teologije upravo možemo čitati kao prilog tezi o nesuvislosti religijskih sukoba.

\subsection{KRITIKA RACIONALNE TEOLOGIJE U GLAVNOM DJELU I. KANTA}

Ovdje - bez prethodnog uvođenja u sadržaj koji prethodi jednoj kritici racionalne teologije u glavnome djelu Immanuela Kanta oslovljenom kao Kritik der reinen Vernunft - bit će predočena kritika ontologijskog dokaza, kozmologijskog dokaza i fizikoteologijskog ili teleologijskog dokaza za egzistenciju religijske ideje Boga unutar jedne kritike racionalne teologije.

\subsection{Nesuvislost ontologijskog dokaza za egzistenciju Boga}

Ontologijski dokaz za egzistenciju Boga mogli bismo označiti kao pokušaj racionalnog bogoopravdanja koji je iznesen među prvim iznesenim dokazima u povijesti racionalne teologije, a koji je imao za cilj na jedan uvjetno rečeno racionalan i sustavan način odgovoriti na pritužbe onih koji su negirali religijsku ideju Boga kao nešto zbiljski egzistentno. Nakon što je Tales napustio epistemologiju antičke Grčke koja se zasnivala na mitologijskim slikama svijeta, krenuvši jednim racionalnim putem odgovoriti na pitanja koja su prožimala svijet antike, sljedbenici racionalnog načina mišljenja nisu željeli vraćati se natrag u mitologiju s nametanjima religijske ideje Boga. Naime, metoda racionalnog promišljanja religijske metafizike nije bila odveć nepoznata $\mathrm{u}$ antici, stoga što je tek Filon Aleksandrijski kao pripadnik jevrejskog društva tumačio Sveti tekst i/ili 
Objavu na takav način da je tražio razumska opravdanja za tvrđenja sadržana u sustavu teologijskog nauka judaizma, a sve kako bi približio jevrejska religijska učenja antičkom svijetu.

Upravo, religijska ideja Boga koja se antičkom načinu mišljenja pričinjavala kao misao zasnovana na pređašnjim mitologijama i postignućima u religijskim nastojanjima Filona Aleksandrijskog bili su povod da religijski autoriteti iznesu jedan ontologijski dokaz za postojanje religijske ideje Boga sa tendencijom da bude takav da bi ga svi morali prihvatiti. Anselmo Kanterberijski bio je prvi koji se suprotstavio bezuspješnim pokušajima njegova prethodnika Ivana Skota Eriugene koji je nastojao opravdati postojanje Boga, ali čije učenje je sadržavalo mnoštvo mističkih, mitoloških i magijskih elemenata zbog čega ontologijski dokaz koji je iznio Anselmo Kanterberijski jeste prvi značajniji pokušaj racionalnog bogoopravdanja. ${ }^{14}$

Ontologijskim argumentom željelo se odgovoriti onima koji negiraju religijsku ideju Boga i određuju je kao nespoznatljivu razumom na takav način što će se ontologijskim argumentom sustavno predočiti metoda dokazivanja postojanja religijske ideje Boga kroz odnošaje Svetog teksta i/ili Objave i razuma. Iako, pokušaj uspostave racionalne metode za opravdanje postojanja Boga prvotno je imao za cilj predočiti razumski prihvatljive razloge bogoopravdavanja, docnije će se ova metoda prenijeti na cjelokupnost pitanja koja se predmeću pred religijsku metafiziku, a na koja je metafizika nastojala odgovoriti još od Aristotelovog projekta sustavnog pristupa metafizici kao prvoj filozofiji. ${ }^{15}$ Dakle, mističko-(novo)platonistički pokušaji Ivana Skota Eriugene temeljeni na panteizmu Pseudo-Dionizija Areopagita bili su nada religijskih autoriteta na početku nastojanja da se odgovori onima koji su negirali religijsku ideju Boga, ali budući da Eriugena usvajajući mističke elemente $\mathrm{u}$ dokazivanjima nije uspio u svojim nastojanjim, a potpao je pod ustanovu anateme od strane religijske institucije rimokatoličkog kršćanstva i sustavni pokušaj Anselma Kanterberijskog se prihvatio kao vrhunac mogućnosti razumskog odgovaranja na negiranje

\footnotetext{
${ }^{14}$ Usp. Porobija, Ž. (1995). Ontološki dokaz za postojanje Boga. Biblijski pogledi 3 (2), str. 107-137.

${ }^{15}$ Usp. Tatakis, V. (2002). Vizantijska filosofija. Nikšić: Jasen.
} 


\section{IZLAGANJE KANTOVE KRITIKE RACIONALNE \\ TEOLOGIJE KAO PRILOGA TEZI O NESUVISLOSTI RELIGIJSKIH SUKOBA}

religijske ideje Boga. ${ }^{16}$ Ontologijski dokaz je odmaknuo se od svih pređašnjih misticizama koji su bili prevalvirajućeg karaktera u ranim pokušajima opravdanja religijske ideje Boga na horizontu Zapada, te je nastojanje da se mistika ostavi po strani izrodilo novi pokušaj predočavanja kompatibilnosti razuma i Svetoga teksta i/ili Objave. ${ }^{17}$

Konačno, ontologijski argument se zasniva na izvođenju postojanja Boga iz samoga pojma Boga jer ukoliko Bogu kao takvom ne bi pripadalo postojanje izvan pojma tada niti sam pojam ne bi mogao postojati - budući da se ideja Boga nalazi u mišljenju, prema riječima Anselma Kanterberijskog, iz toga proizlazi postojanje Boga i izvan mišljenja, dakle u samoj zbilji jer ukoliko Bog ne bi postojao u samoj zbilji onda ne bi bilo mogućno da Bog bude sadržaj mišljenja i ne bi mogao biti religijska ideja, uopće. Sukladno ovako postavljenome ontologijskom dokazu za postojanje Boga proizlazi da sve što postoji u mišljenju nužno mora imati egzistenciju i izvan mišljenja stoga što ne bi moglo biti sadržaj mišljenja ukoliko kao takvo ne postoji u zbilji. Sama ideja Boga ukazuje na biće od kojega se ne može zamisliti ništa savršenije i veće, te da kao takvo se nalazi u mišljenju i onih koji negiraju religijsku ideju Boga jer samo takvo jedno savršeno biće i mogu zamisliti. Samo negiranje religijske ideje Boga upućuje da oni koji je negiraju u svojemu mišljenju posjeduju ideju Boga što ukazuje da Bog mora postojati jer ukoliko ne bi postojao ne bi mogao biti sadržaj njihova mišljenja. Ukoliko se religijskoj ideji Boga u mišljenju kao savršenom i

\footnotetext{
${ }^{16}$ Usp. Bloch, D. (2007). Aristotle on Memory and Recollection: Text, Translation, Interpretation, and Reception in Western Scholasticism. Leiden: Brill Academic Publishers.

${ }^{17}$ Govor o ontologijskom dokazu kao dokazu Anselma Kanterberijskog nameće se u ovomu kontekstu kao takav shodno predominaciji religijskih autoriteta koji su zastupali racionalnu teologiju imajući višestoljetnu institucionaliziranost religijske institucije rimokatoličkog kršćanstva utemeljenje na racionalnoj teologiji u odnosu na sljedbenike racionalne teologije u drugim religijama. Anselmo Kanterberijski postao je crkveni otac, dok Filon Aleksandrijski, koji je bio pripadnik jevrejske zajednice, nije imao značajnija fundiranja u sustavu teologijskog nauka bilo koje škole judaizma, ili primjerice $\mathrm{u}$ islamu sljedbenici racionalne teologije koji su uspjeli institucionalizirati religijsku instituciju utemeljenu na racionalnoj teologiji nepuno jedno stoljeće.
} 
najvećem biću oduzme postojanje u svijetu, tada zapravo to savršeno i najviše biće ne bi moglo biti savršeno zbog izostanka postojanja, a što je nemoguće. Tako, Anselmo Kanterberijski ustanovljuje da postoji biće od kojega se ništa veće ne može zamisliti i kao takvo sadržano je u mišljenju kao i svijetu. ${ }^{18}$ Najkraće rečeno, takvo razumijevanje dokaza za postojanje Boga se naziva ontologijskim i iako je koncipirano tako da bude razumljivo i običnome puku, ono predstavlja prvi sustavno racionalan pristup bogoopravdanju na kojemu se docnije zasnivala mnogobrojna religijska literatura koja je imala za cilj detaljnije objasniti ontologijski dokaz i sustavnije ga urediti. Tako usredsređen ontologijski argument očekivano je zadobio mnoštvo prigovora koji su izloženi još u vremenu Anselma Kanterberijskog nakon čega je Kanterberijski pisao nova djela kao odgovori na prigovore, ali njegovi odgovori nisu bili dostatni da prigovori za ontologijski argument budu okončani negoli su izlagani tijekom cjelokupne povijesti mišljenja gdje posebito mjesto zauzima Immanuel Kant u svojemu djelu Kritik der reinen Vernunft.

Naime, u pretkritičkom periodu Kant zastupa tezu o nemogućnosti jednog ontologijskog dokaza za egzistenciju Boga gdje se egzistencija stvari izvodila iz samoga pojma stvari, stoga što je nemogućno egzistenciju izvoditi iz pojma zbog čega Kant se u potpunosti protivio mogućnosti obrazovanja jednog takvog dokaza. U Kantovom metafizičkom periodu, kao i njegovom kritičkom periodu koji je uslijedio nakon perioda poznatog kao desetogodišnja šutnja, od presudne važnosti glede pitanja epistemologije jeste razumijevanje iskustva, pa tako Kant odbacuje za mogućno izvoditi u iskustvu nešto što je po svojoj prirodi izvan mogućnosti svakog iskustva nego je sadržano u mišljenju - kada govorimo o egzistenciji bilo čega uvijek potvrdu te egzistencije tražimo u iskustvu i kada govorimo da nešto postoji uvijek takvu tvrdnju izričemo na osnovu iskustva. Dakle, iskustvo kao centralni pojam Kantove epistemologije jeste određujuće u pitanju da li nešto jeste egzistentno ili nije egzistentno, a što je Kant osobito pokazao u kritičkom periodu gdje u djelu Kritik der reinen Vernunft u poglavlju jednog nauka Transcendentalne analitike određuje da samo ono što je u području iskustva može biti sadržaj saznanja. Budući da religijska ideja Boga nije

${ }^{18}$ Usp. Kanterberijski, A. (1997). Proslogion. Zagreb: Demetra. 


\section{IZLAGANJE KANTOVE KRITIKE RACIONALNE \\ TEOLOGIJE KAO PRILOGA TEZI O NESUVISLOSTI RELIGIJSKIH SUKOBA}

sadržana u iskustvu, iz toga proizlazi da religijska ideja Boga ne može biti dokaziva kao drugi sadržaji iskustva, nego ona ostaje daleko od mogućeg dokazivanja na takav način govoreći o nemogućnosti jednog ontologijskog dokaza koji bi se temeljio na postavkama koje je ustanovio Anselmo Kanterberijski i na kojima se ontologijski dokaz docnije kroz povijest mišljenja na horizontu Zapada razvijao. ${ }^{19}$ Ovakvo Kantovo pobijanje ontologijskog dokaza i njegovo zanimanje za metode racionalne teologije uvjetovalo je docnija zanimanja za ontologijski dokaz glede pitanja egzistencije Boga od gotovo svih značajnijih mislitelja, a među posljednjima koji je pokušao osporiti Kantove argumente i dati prigovor bio je Alvin Plantinga koji u svojim nastojanjima ipak umnogomu nije uspio. ${ }^{20}$

Napose, opovrgavanjem mogućnosti jednog ontologijskog dokaza za egzistenciju Boga Kant nije negirao postojanje Boga, nego je ukazao da „,iako se egzistencija izvan ovoga polja ne može oglasiti za potpuno nemoguću, ipak je ona jedna pretpostavka koju ne možemo opravdati“ ${ }^{\text {21 }}$. Na taj način ukazao je da je ontologijski dokaz nemoguć stoga što nije moguće na razumskim osnovama dokazati egzistenciju religijske ideje Boga, ali s druge strane nije moguće niti negirati je. Kant na jednom mjestu kaže da je ideja Boga tako velika da su riječi, brojevi i sva naša nastojanja nedovoljni da je opišu, a kamoli da je dokažu racionalnim načinom mišljenja.

\subsection{O nemogućnosti utemeljenja kozmologijskog dokaza za egzistenciju Boga}

$\mathrm{Na}$ samome početku postavljanja pitanja o kozmologijskom dokazu za egzistenciju Boga neophodno je ukazati na antinomije čistoga uma koje se javljaju kao suprotstavljanje jedne teze naspram antiteze koja je obrazovana kao negacija prvotno postavljene teze gdje se teza kao i antiteza javljaju izvan svake moguće granice iskustva pretendirajući da budu izložene $\mathrm{u}$

\footnotetext{
${ }^{19}$ Usp. Kant, I. (1976). Kritika čistog uma [predgovor: Veljko Korać, preveo: Nikola Popović]. Beograd: BIGZ.

${ }^{20}$ Usp. Plantinga, A. (1974). The Nature of Necessity. Oxford: Clarendon Press.

${ }^{21}$ Kant, I. (1976). Kritika čistog uma [predgovor: Veljko Korać, preveo: Nikola Popović]. Beograd: BIGZ, str 369-370.
} 
području iskustvenosti. Pitanja koja nadilaze granice mogućeg iskustva kroz cjelokupnu povijest mišljenja nastoje se opravdati u iskustvu, na takav način želeći zadobiti znanstvenu objektivnost, gdje se zapravo ta navodna znanstvena objektivnost javlja kao krajnja subjektivnost, a ono što je moguće samo kao subjektivno želi se predočiti kao znanost jednaka logici ili matematici ili prirodnoj znanosti. Budući da su pitanja o kojima se raspravlja u ovomu kontekstu izvan iskustva, postuliranje teze za neko pitanje sasvama izvjesno otvara prostor za formiranje antiteze koja će biti oprečna onomu što se postuliralo u samoj tezi i što se željelo predočiti kao krajnje znanstveno objektivno. Nije strana pojava kako se i svaka antiteza pojavljuje kao teza na osnovu čega se formira nova antiteza i takvo poprište dijalektičkih sukoba ne poznaje granice u koje treba omeđiti svoje proturječnosti, negoli svoje igrarije postavljaju prevalvirajućim u metafizici. $\mathrm{Na}$ tomu tragu, Kant zasniva jednu antitetiku kao puku suprotnost skupini dogmatskih tvrđenja koja daleko od dokaza teze i dokaza antiteze zauzima položaj sveobuhvatnog razmatranja dijalektičkih sukoba upozoravajući na antinomičnost izvjesnih tvrđenja. ${ }^{22}$

I, s obzirom na primat četvrte antinomije za uvođenje u kritiku racionalne teologije i govor o nemogućnosti jednog kozmologijskog dokaza za egzistenciju Boga, Kant navodi tezu da svijetu pripada nešto što je njegov dio ili kao njegov uzrok dok s druge strane istodobno se javlja antiteza koja se ogleda u tvrđenju da u svijetu niti izvan njega ne egzistira biće koje je upravo nužno kao njegov uzrok. Teza kao i antiteza imaju određena tvrđenja gdje se antiteza javlja kao oprečna tvrđenju teze i ukoliko bi se izložili dokazi i teze i antiteze obje strane bi imale manje ili više uspješne argumente, te bi bilo nemogućno presuditi koja od dva ili više oprečnih stajališta zauzimaju stepen više izvjesnosti stoga što ovo pitanje kojim se četvrta antinomija bavi nadilazi granice svakoga mogućeg iskustva zbog čega je nemogućno argumentacije bilo koje od dvije ili više suprotstavljenih strana provjeriti u iskustvu. Svako ko bi krenuo u istraživanja izvjesnosti teze ili antiteze i ukoliko već unaprijed ne bi slijedio neki od izrečenih stavova, bio bi u prilici neprestano mijenjati svoju poziciju te smatrati

${ }^{22}$ Usp. Kant, I. (1976). Kritika čistog uma [predgovor: Veljko Korać, preveo: Nikola Popović]. Beograd: BIGZ, str. 261. 


\section{IZLAGANJE KANTOVE KRITIKE RACIONALNE \\ TEOLOGIJE KAO PRILOGA TEZI O NESUVISLOSTI RELIGIJSKIH SUKOBA}

izvjesnom tezu ili antitezu, pa ponovno tezu ili antitezu itd. ${ }^{23} \mathrm{Na}$ tomu tragu treba ukazati na povijest kozmologijskog dokaza na horizontu Zapada i kazati kako uspostavitelj kozmologijskog dokaza za egzistenciju religijske ideje Boga jeste Toma Akvinski koji je poricao mogućnosti jednog ontologijskog dokaza za egzistenciju Boga stoga što je držao kako je osjetilnost ono od čega u osnovi polazi svako saznanje i stoga nije za potrebito izlaziti van iskustva kao u dokazivanjima Anselma Kanterberijskog kako bi se došlo do bogoopravdanja. Ono što razlikuje Tomu Akvinskog od njegovih prethodnika, krenuvši od Filona Aleksandrijskog preko PseudoDinonisija Areopagita, pa i Anselma Kanterberijskog, jeste to što Toma Akvinski uzima u obzir iskustvo kada kaže da upravo iskustvo jeste jedini put u kojemu može da se kreće razum, a ne da se bavi pitanjima izvan područja iskustva. $^{24}$

$\mathrm{Na}$ tomu tragu, kozmologijski dokaz je doživio svoju vrlu prijemčivost $\mathrm{u}$ religijskim krugovima među religijskim autoritetima zbog čega se razvijao u dva smjera od kojih je jedan dokaz iz kauzalnosti, a drugi dokaz iz kontingencije. Kant je pokazao kako oba dokaza su svodiva na jedan, a poznato je u povijesti racionalne teologije da su i mnogi religijski autoriteti ova dva dokaza svodili na po jedan objedinjavajući. Tako, kozmologijski dokaz se ogledao u tezi kako sve što jeste slučajno mora imati i svoj uzrok da bi se cijeli niz uzroka vodio do prvoga uzroka ili u ovomu kontekstu racionalne teologije do samoga Boga. U svojemu pretkritičkom periodu Kant je uveliko bio sumnjičav spram kozmologijskog dokaza za egzistenciju Boga, da bi u kritičkom periodu tvrdio kako je kozmologijski dokaz za egzistenciju Boga samo gnijezdo pretjeranih dijalektičkih zahtjeva držeći kako osnovni stav kozmologijskog dokaza, bilo da je riječ o dokazu iz kauzaliteta ili dokazu iz kontingencije, mora ležati u iskustvu i kako je prekoračivanje iskustvenosti besmisleno. Ono što je zanimljivo jeste da je Toma Akvinski za razliku od svojih prethodnika operirao pojmom iskustva, ali razvojnu liniju kozmologijskog dokaza za egzistenciju Boga nije upravio

\footnotetext{
${ }^{23}$ Usp. Cornman, J. W., Lehrer, K., Pappas, G. S. (1992). Philosophical Problems and Arguments: An Introduction. Indianapolis: Hackett.

${ }^{24}$ Usp. Akvinski, T. (2005). Izabrano djelo. Zagreb: Globus.
} 
spram iskustva nego je ipak prekoračio. Razlog prekoračivanja iskustva jeste $\mathrm{u}$ onome momentu kada se $\mathrm{u}$ iskustvu nije mogao pronaći taj prvi uzrok do kojega je vodio cijeli niz uzroka, zbog čega su Toma Akvinski i njegovi sljedbenici napustili iskustvo kako bi mogli postaviti religijsku ideju Boga kao krajnje nužnoga bića. Toma Akvinski je na sve moguće načine pokušao izbjeći ontologijski dokaz na kojemu je insistirao Anselmo Kanterberijski kako ne bi morao religijsku ideju Boga kao egzistenciju izvoditi iz pojma, ali upravo je prekoračivanjem iskustva uveo ontologijski dokaz u kozmologijski dokaz za egzistenciju Boga zbog čega se kozmologijski dokaz zapravo svodi na ontologijski. ${ }^{25}$

Dakle, Kantov glavni i osnovni prigovor kozmologijskom dokazu za egzistenciju Boga bez zadiranja u njegove pojedinosti jeste to što je u njemu na djelu napuštanje područja iskustva na koje se pozivaju religijski autoriteti glede ovoga dokaza za egzistenciju religijske ideje Boga i podvođenje ontologijskog dokaza za egzistenciju Boga pod kozmologijski dokaz na način da se razvojna linija kozmologijskog dokaza u iskustvu prekinula onoga trenutka kada se pretpostavila egzistencija na osnovu samoga pojma religijske ideje Boga. Ovdje, dakle u kozmologijskom dokazu, pretpostavio se pojam jednog nužnog bića - u racionalnoj teologiji razumijevan religijskom ideja Boga - kao samorazumljiv, kao i da izvođenje egzistencije Boga iz pojma religijske ideje Boga predstavlja jednu apsolutnu nužnost.

\subsection{Opovrgavanje mogućnosti jednog fizikoteologijskog ili teleologijskog dokaza za egzistenciju Boga}

Kantova kritika racionalne kozmologije i kritika racionalne teologije onemogućila je svako raspravljanje putem racionalne metode o pitanjima koja nadilaze iskustvo, pa svejedno govorila ona o prvom uzroku ili savršenom biću sadržanom u religijskoj ideji Boga, ali pitanja koja nadilaze iskustvo s tim ne prestaju nego se iznova zasnivaju i metafizika kao takva se zasniva upravo na pitanjima koja nadilaze svako moguće iskustvo. Ontologijski dokaz koji se pokazao nedovoljno akribičnim da opravda

25 Usp. Porobija, Ž. (1996) Kozmološki dokaz za egzistenciju Boga. Biblijski pogledi 4 (1), str. 19-38. 


\section{IZLAGANJE KANTOVE KRITIKE RACIONALNE \\ TEOLOGIJE KAO PRILOGA TEZI O NESUVISLOSTI RELIGIJSKIH SUKOBA}

nastojanja Anselma Kanterberijskog i kozmologijski dokaz Tome Akvinskog koji se u svojoj osnovi svodio na prvobitni ontologijski dokaz pokazao se kao nemoguć, pa su se čak i pokušaji Pseudo-Dionisija Areopagita ili Ivana Skota Eriugene pokazali kao prijemčiviji zbog mitoloških i magijskih elemenata kojih se nije moglo osporiti kao racionalne, negoli ih se moglo samo prihvatiti kao takve ili napose odbiti. Upravo, na tomu tragu, ponajstariji dokaz za egzistenciju Boga i vezivao se za mitologijske i magijske elemente dok nije sustavno uređen i podveden pod racionalnu metodu dokazivanja u teologiji Tome Akvinskog kao peti put dolaska do Boga, a to je fizikoteologijski ili teleologijski dokaz za egzistenciju Boga. ${ }^{26}$

Iako Kant upozorava da je fizikoteologijski ili teleologijski dokaz za egzistenciju Boga udaljen od formalno logičkog puta u svojemu prvome dijelu kada upućuje na uređenost svijeta, ipak je najprihvaćeniji od svih drugih mogućih dokaza za egzistenciju Boga i o njemu se uvijek govorilo sa dubokim poštovanjem. Upravo njegova udaljenost od formalno logičkog puta u svojemu prvom dijelu je razlog zbog kojega ovaj dokaz za egzistenciju Boga i završava kod Tome Akvinskog na petom i posljednjem mjestu u sistematizaciji puteva koji vode ka spoznaji Boga, ali razlog k tomu jest upravo taj što je fizikoteologijski ili teleologijski dokaz bio dokazom prije uspostave racionalne teologije i ideje o načinu dokazivanja Boga kod Anselma Kanterberijskog. Naime, fizikoteologijski ili teleologijski dokaz za egzistenciju Boga se ne pita kao kozmologijski dokaz za egzistenciju Boga o tomu zašto svijet uopće jeste, nego postavlja pitanje: zašto svijet tako uređen uopće jeste!? Fizikoteologijski ili teleologijski dokaz za egzistenciju Boga se poziva na savršenstvo svijeta, na smjenu dana i noći, na promjene godišnjih doba, na funkcioniranje ljudskoga tijela kao dokaz uređenosti koju mora priznati čak i ponajveći bezbožnik i neznabožac. Fizikoteologijski ili teleologijski dokaz za egzistenciju Boga insistira kako je sve u svijetu uređeno prema nekome cilju, što navodi na zaključak da mora postojati neki uzvišen i mudar uzrok, naime neka inteligencija koja djeluje iz slobode, a budući da je riječ o jedinstvu svijeta tada i priliči jedinstvo pomenute nužne

${ }^{26}$ Usp. Akvinski, T. (1990). Izbor iz djela: Summa theologiae. Zagreb: Naprijed, str. 174. 
inteligencije, nikako mnoštva njih. Napose, fizikoteologijski ili teleologijski dokaz za egzistenciju Boga tvrdi da je nužna inteligencija identitarna religijskoj ideji Boga. ${ }^{27}$

Kantov stav prema fizikoteologijskom ili teleologijskom dokazu za egzistenciju Boga se mijenjao: od odnosa kada je držao da o spomenutome dokazu treba govoriti s poštovanjem ${ }^{28}$ do teze kako se i fizikoteologijski ili teleologijski dokaz svodi na ontologijski dokaz za egzistenciju Boga, da je ontologijski dokaz u njemu skriven i da se fizikoteologijski ili teleologijski dokaz na njemu zapravo i zasniva. ${ }^{29}$ Razlog $\mathrm{k}$ tomu je što sljedbenici racionalne teologije izvode od nužne inteligencije religijsku ideju Boga, a prema Kantu nikada niti jedno iskustvo ne može biti adekvatno jednoj religijskoj ideji Boga stoga što je ideja nužnog bića tako velika i u takvom omjeru nadilazi svako moguće iskustvo da je daleko od svega onoga što nam je poznato u iskustvu i stoga nikada na osnovu samoga iskustva ne možemo doći do znanja o njoj. Kant drži kako su sve naše riječi, svi brojevi, sve boje tako mali u odnosu na nužno biće da možemo imati samo nijemi odnos divljenja ostajući uskraćeni mogućnosti osjetilima unutar iskustva pojmiti religijsku ideju Boga. Ovakvo Kantovo odustajanje od fizikoteologijskog ili teleologijskog dokaza za egzistenciju Boga u kritičkom periodu razložno je uviđaju kako iz same svrhovitosti koja je krajnje aposteriorna nije moguće izvoditi jednu transcendentalnu ideju i pri tomu njezinu egzistenciju stoga što je takvo što izvan svakog mogućeg iskustva i izvan svake mogućnosti, uopće. Zasnivanje fizikoteologijskog ili teleologijskog dokaza za egzistenciju religijske ideje Boga se prema tomu zasniva na ontologijskom dokazu za egzistenciju Boga koji je odveć pokazan kao nemoguć zbog njegovog nastojanja da iz religijske ideje pojma Boga izvodi i egzistenciju Boga, a

${ }^{27}$ Usp. Porobija, Ž. (1996). Teleološki dokaz postojanja Boga. Biblijski pogledi 4 (2), str. 105.

${ }^{28}$ Usp. Kant, I. (1989). Opća povijest prirode i teorija neba ili pokušaj o ustrojstvu $i$ mehaničkom postanku cijele svjetske zgrade raspravljena po Newtonovim principima [prijevod: Mile Babić, predgovor: Milan Damjanović]. Sarajevo: Svjetlost, str. 139.

${ }^{29}$ Usp. Kant, I. (1976). Kritika čistog uma [predgovor: Veljko Korać, preveo: Nikola Popović]. Beograd: BIGZ, str. 379. 


\section{IZLAGANJE KANTOVE KRITIKE RACIONALNE \\ TEOLOGIJE KAO PRILOGA TEZI O NESUVISLOSTI RELIGIJSKIH SUKOBA}

takvo što Kant određuje kao tendenciju koja u svojemu posjedu nema nužnu apodiktičku izvjesnost.

\subsection{ZAKLJUČNI GOVOR}

Shodno svemu izloženome možemo u zaključnome govoru napraviti pogled unatrag zbog postulirane hipoteze i razlagane argumentacije u korist dokazivanja iste, te kazati kako je u ovomu radu razmatrano djelo Immanuela Kanta kroz njegov pretkritički, metafizički i kritički period, a u kontekstu postavljanja pitanja o jednoj kritici racionalne teologije. Ipak, prvashodno prednost je dana Kantovom glavnom djelu oslovljenom kao Kritik der reinen Vernunft u kojemu se eksplicitno izlaže jedna kritika racionalne teologije uz kritiku racionalne kozmologije i racionalne psihologije kao sastavnica srednjovjekovne metaphysica-e specialis. A svemu tome, prethodio je kontekstualiziran prikaz kratke povijesti mišljenja jednoga fenomena imenovanoga kao racionalna teologija da bi nakon toga u dijelu oslovljenom kao proemium za jednu kritiku racionalne teologije bio predočen Kantov odnos spram osnovnih teologijskih epistemologija i to epistemologije fundamentalne teologije, epistemologije racionalne teologije i epistemologije spiritualne teologije: ovakav Kantov odnos spram teologijskih epistemologija je komparativno problematiziran kroz njegov pretkritički, metafizički i kritički period da bi naposljetku bile predočene osnovne značajke same Kantove kritike racionalne teologije. Naposljetku, hipoteza ovoga rada se ogledala u dokazivanju odnosa između Kantove kritike racionalne teologije i ideje o nesuvislosti religijskih sukoba na način da se nesuvislost religijskih sukoba temelji zapravo u rezultatima Kantovoga kriticizma: nemogućnosti uspostave ontologijskog, kozmologijskog i fizikoteologijskog ili teleologijskog dokaza za egzistenciju religijske ideje Boga na nivou objektivnosti, izvjesnosti i znanja. Upravo, u trećem dijelu rada prikazano je Kantovo izlaganje spomenutih nemogućnosti što ukazuje kako se zapravo rezultati Kantovoga glavnog djela Kritik der reinen Vernunft daju kao takvi da se postavlja pitanje: zašto uopće ozbiljivati religijske sukobe kada ne možemo objektivno dokazati egzistenciju religijske ideje Boga - zbog koje se sāmi religijski sukobi i ozbiljuju!? Jer, 
polazeći s pozicije njemačkog idealizma Kant je vjeru stavio između 'mnijenja' kao najnižeg stupnja izvjesnosti i 'znanja' kao najvišeg i definirao je kao 'držati za istinito;' i k tomu je ona samo 'subjektivno dostatna,' ali se 'objektivno mora držati za nedostatnu. ${ }^{\text {'“630 }} \mathrm{Na}$ tomu tragu hipoteza iskazana ovdje proistjecala je zapravo iz grandioznosti građevine kakva je jedna kritika racionalne teologije koja je zapravo utjecala na cjelokupni docniji razvoj mišljenja na horizontu Zapada napućujući nesuvislosti samih religijskih sukoba što je bio i jedan od povoda pisanja ovoga rada - čemu se možemo osvjedočiti u samim prepiskama Immanuela Kanta kao i njegovu poznome djelu oslovljenom kao Zum ewigen Frieden. ${ }^{31}$

\section{LITERATURA}

Akvinski, T. (2005). Izabrano djelo. Zagreb: Globus.

Akvinski, T. (1990). Izbor iz djela: Summa theologiae. Zagreb: Naprijed.

Bartov O., Mck P. (2010) In God's Name: Genocide and Religion in the Twentieth Century. Brooklyn: Berghahn Press.

Bloch, D. (2007). Aristotle on Memory and Recollection: Text, Translation, Interpretation, and Reception in Western Scholasticism. Leiden: Brill Academic Publishers.

Cabezón, J. I. (1998). Scholasticism: Cross-Cultural and Comparative Perspectives. Albany: SUNY Press.

Cornman, J. W., Lehrer, K., Pappas, G. S. (1992). Philosophical Problems and Arguments: An Introduction. Indianapolis: Hackett.

Del Val, M. (1938). Index librorum prohibitorum, SS.MI D. N. PII PP. XI iussueditus. Vatikan: Typis Poliglottis Vaticanis.

Filipović, Vladimir (1989). Filozofijski rječnik; NZMH, Zagreb.

Gascón, A. (2007). Reason, Revelation, and Faith of the Heart. Dayton, Ohio: NACMS.

Grbić, S. (2018). Mišljenje religijskih sukoba kao sukobljavanje epistemologija. Theoria vol. 4 no. 4.

Kanterberijski, A. (1997). Proslogion. Zagreb: Demetra.

Kant, I. (1976). Kritika čistog uma. Beograd: BIGZ.

\footnotetext{
${ }^{30}$ Filipović, Vladimir (1989). Filozofijski rječnik; NZMH, Zagreb, str. 351.

${ }^{31}$ njem. Prema vječnom miru. Usp. Kant, I. (2000). Pravno-politički spisi. Zagreb: Politička kultura, str. 113.
} 


\section{IZLAGANJE KANTOVE KRITIKE RACIONALNE TEOLOGIJE KAO PRILOGA TEZI O NESUVISLOSTI RELIGIJSKIH SUKOBA}

Kant, I. (2000). Latinska djela. Zagreb: Hrvatski studiji.

Kant, Schelling, Schopenhauer. (2008). Ogledi o vidovitosti [Kant: Snovi jednog vidovnjaka protumačeni snovima metafizike]. Zagreb: Hrvatska sveučilišna naklada.

Kant, I. (2000) Pravno-politički spisi. Zagreb: Politička kultura.

Kant, I. (1989). Opća povijest prirode $i$ teorija neba ili pokušaj o ustrojstvu $i$ mehaničkom postanku cijele svjetske zgrade raspravljena po Newtonovim principima [prijevod: Mile Babić, predgovor: Milan Damjanović]. Sarajevo: Svjetlost, str. 139.

Porobija, Ž. (1995). Ontološki dokaz za postojanje Boga. Biblijski pogledi 3 (2), str. $107-137$.

Porobija, Ž. (1996) Kozmološki dokaz za egzistenciju Boga. Biblijski pogledi 4 (1), str. 19-38.

Porobija, Ž. (1996). Teleološki dokaz postojanja Boga. Biblijski pogledi 4 (2), str. 105.

Plantinga, A. (1974). The Nature of Necessity. Oxford: Clarendon Press.

Tatakis, V. (2002). Vizantijska filosofija. Nikšić: Jasen.

Wainwright, W. J. (2016). Reason, Revelation and Devolution. New York: Cambridge University Press. 


\title{
SAFER GRBIĆ
}

University of Zagreb, Faculty of Humanities and Social Sciences,

Croatia

\author{
EXPOSITION OF KANT'S CRITIQUE OF RATIONAL \\ THEOLOGY AS A CONTRIBUTION TO THE THESIS ON \\ INCOHERENCE OF THE RELIGIOUS CONFLICTS
}

\begin{abstract}
What is the significance of Kant's critique of metaphysics and in particular of his critique of rational theology in the context of the question of the incoherence of religious conflicts? Precisely concerning this relationship, this paper will consider a brief history of thinking of a phenomenon called rational theology, then in this context, we will consider Kant's precritical work and later presentation of a critique of rational theology, all in the context of questioning the relationship enumerated with religious conflicts. The hypothesis of this paper is reflected in proving the relationship between Kant's critique of rational theology and the idea of the inconsistency of religious conflicts in such a way that the inconsistency of religious conflicts is based on the results of Kant's critique: the impossibility of certainty and knowledge. So, finally, and according to the results of Kant's main work Kritik der reinen Vernunft: why make religious conflicts serious at all when we cannot objectively prove the existence of the religious idea of God - who is the reason religious conflicts themselves, by their definition, are serious!?
\end{abstract}

Keywords: gnoseology, theological epistemology, rational theology, Immanuel Kant, religious conflicts, triplet, revelation, reason, heart

Primljeno: 16.2.2021. Prihvaćeno: 17.5.2021. 